\title{
ブルガリア正教徒商人による商業施設の建設と交易空間 \\ - 19 世紀のタルノヴォを事例としてー
THE CONSTRUCTION OF COMMERCIAL BUILDINGS BY BULGARIAN ORTHODOX MERCHANTS AND THEIR SPATIAL CHARACTER

- The case study of Turnovo in the 19th century -

\author{
早坂 由美子
}

Yumiko HAYASAKA

\begin{abstract}
This paper will discuss the construction and utilization of commercial buildings in the middle of the nineteenth century in Turnovo, Bulgaria. The company "Nikola Minchoolu \& Evstati Selveli \& Co.", established by Bulgarian orthodox merchants, had its own large commercial building (khan) and storehouse (maaza) in the commercial quarter of Turnovo. The maaza was built for the company's own business while the rooms of the khan were rented by other people. The khan also functioned as a kind of market. It is concluded that these commercial facilities of the company provided the space of trade and craft chiefly for non-Muslims.
\end{abstract}

Keywords: Bulgarian orthodox merchants, Turnovo, Khan, Maaza (Storehouse), Dyukyan (Shop, Studio), The Ottoman Empire ブルガリア正教徒商人，タルノヴオ，隊商施設，商業倉庫，店舗・工房，オスマン帝国

\section{1. 序}

本研究は、19 世紀中葉のオスマン帝国統治下のバルカン半島 1) 南部における交易空間の様相を解明する試みの一つである。

地理上、バルカン半島は古くから東西文明の境界域であり、19世 紀にはイスラーム世界とヨーロッパ世界の境界・接点であった。本 稿の対象地域であるブルガリアは、14 世紀末から 19 世紀末までの 約 500 年間、オスマン帝国の統治下に置かれていた2)。オスマン帝 国臣民は複数の宗教徒によって構成されており、今日のブルガリア に相当する地域では、オスマン帝国統治以前から居住していた東方 正教徒、統治後に入植したムスリムが人口の大半を占め、その他ユ ダヤ教徒なども一定数居住していた ${ }^{3)}$ 。本研究は 19 世紀オスマン帝 国下のブルガリア正教徒商人に着目し ${ }^{4)}$ 、このような宗教・文化が 混在する状況下で形成された商業空間・交易空間の持つ形態・論理 を明らかにすることを目的としている。

本稿では一つの事例として 19 世紀におけるバルカン半島南部の 重要な交易拠点の一つであったブルガリア中央北部の都市タルノヴ オ 5)と、タルノヴオに本拠地を置いたブルガリア正教徒商人の合同 会社「ニコラ・ミンチョオル\&エフスタティ・セルヴェリ商会」(以 下、ミンチョオル\&セルヴェリ商会）がタルノヴオに建設・所有し た商業施設であるハン（Хан、隊商施設）6）とマアザ（Мааза、商 業倉庫）7)を取り上げる。これら商業施設の建築的特徽および機能・ 利用について検討することで、19 世紀オスマン帝国下においてブル ガリア正教徒が構築した交易・商業空間の実態を明らかにする。
本稿は八章構成である。二章では先行研究、三章では本研究が用 いている史料について解説する。四章ではタルノヴオの 19 世紀に おける交易的役割、タルノヴオ市街地における商業地区の分布とそ の特性、ならびにミンチョオル\&セルヴェリ商会所有の商業施設の 立地について分析する。五章では商会所有のハンについて実測図に 基づいて建築的特徵を検討し、六章では文書史料からハンの利用と 機能を検討する。七章では同商会所有のマアザについて建築的特徴 と利用・機能の側面から検討している。八章は結論である。

19 世紀のオスマン帝国で活動した商人には、ムスリム商人、非ム スリム臣民の商人、ムスターミン商人がいた 8)。ブルガリア正教徒 商人は非ムスリム臣民の商人に分類される。ミンチョオル\&セルヴ エリ商会（1841 年設立、1865 年倒産）は主に中欧一オスマン帝国 間の輸出入・卸売業に従事しており、同時代に設立されたブルガリ ア正教徒の商会の中でもかなり大型の商会であった。事業最盛期で あった 1850 年代後半から 1860 年代前半には、同商会はウィーン、 イスタンブル、ドナウ川下流域のヴィディン、ルセ、そして創業地 かつ本拠地であったタルノヴオに拠点を持ち、陸運と水運による流 通ネットワークを駆使して事業を展開した 9)。

\section{2. 先行研究}

これまでブルガリアの都市や建築が日本において研究対象となら なかった理由は以下のように考えられる。一点は、入手できる情報 が不足しており、確たるイメージがなかったこと。もう一点は、帰 
属する文化圈を判別しにくく、ヨーロッパ都市やイスラーム都市と いう枠組みで行われてきた従来の都市史研究からは漏れてきたとい うことである。この問題はバルカン半島が境界域であり、キリスト 教文化とイスラーム教文化のどちらの要素も持ち合わせている点と つながる。

オスマン帝国都市史研究としてのブルガリア都市史研究もあり得 るが、実際にはイスタンブルまたはアナトリアが主要研究対象とな っており、バルカンに関する研究は少ないのが現状である ${ }^{10)}$

当地における都市史研究は建築史と社会経済史の分野から行われ ている。ブルガリア人建築史学者トドル・ズラテフの研究には 18 、 19 世紀の都市形成に関寸る分析・考察がある ${ }^{11)}$ 。商業地区や商業建 築に関しても実測調查や街路図を基に形態分析をしているが、社会 的文脈から切り離されている点は否めない。

社会経済史からの都市史研究は、人口統計や社会構造を主として 扱っており、物理的な都市空間はあまり考慮されていない12)。本研 究では、物理的な建築空間の分析と文献史料から得られる社会的な 情報を総合して都市における交易・商業空間を考察する。

\section{3. 史料}

一次史料となる文献史料には、ブルガリア国立文書館ヴェリコ・ タルノヴオ分館所蔵 $\Phi 82$ K. Оп. 1, 2 「ニコラ・ミンチョオル \&エフ スタティ・セルヴェリ商会」とブルガリア国立図書館ブルガリア歴 史アーカイヴ所蔵 $\Phi 49$.「八ジ・ニコラ・ディモフ・ミンチョオグ ル」としてまとめられた文書群を用いる。文書史料の大半を占める のは、商会の帳簿、商会内の拠点往復書簡、帝国内外の主に正教徒 の商人とやり取りした書簡、不動産売買 ・賃貸契約書である。同館 所蔵の $\Phi 65 \kappa$ 「タルノヴオ州の古文書群」にも同商会に関係する文 書が含まれるため、こちらも用いる。

絵図史料は、筆者作成による実測図面とヴェリコ・タルノヴオ歴 史博物館所蔵の写真史料を中心に用いる。本稿の分析対象であるミ ンチョオル\&セルヴェリ商会所有の商業施設に関しては、ハン（現 存) の実測図面、古写真、数枚の文書、およびマアザ (1913 年倒壞) の古写真と文書がある。タルノヴオの都市図として 1876 年ロシア 軍将校スホムリノフ作成の地図 ${ }^{13)} 、 1960 \sim 70$ 年代作成（推定）の 等高線入り 地籍図 14$) 、 2003$ 年の地籍図を用いる。

\section{19 世紀における交易拠点としてのタルノヴォ}

本章では、ミンチョオル\&セルヴェリ商会所有の商業施設を検討 する前提として、19 世紀のタルノヴオの交易的役割と中心商業地区 の特徴、商会所有のハンとマアザの立地について確認しておきたい。

タルノヴオは、ブルガリアの国土を東西に横切るスタラ山脈と現 在はルーマニアとの国境となっているドナウ川との中間地点に位置 する都市である。旧市街は大部分が急勾配の丘陵地で、ぐるりと川 に囲まれた半島状の地形を呈する (図 2)。地形からみて軍事的条件 に優れていたことは明らかであり、中世の第二次ブルガリア帝国 （1185 年-1393 年）の首都として選定され、この時代から本格的な 都市として発展したと考えられる。14 世紀末にオスマン帝国の統治 下に入ると、周辺地域の経済・行政中心都市となり 15 )、市街東端部 に位置する中世の城砦地区は居住地区として再開発され、その西側
の比較的緩やかな斜面に新たな市街地が形成されていった。19 世紀 の人口は一万人から二万人の間で推移し、ムスリムと非ムスリムが 20 のマハラ (Махала) に分かれて居住していた ${ }^{16)}$ 。1865 年 12 月 22 日の統計では非ムスリム人口はムスリム人口のほぼ二倍であり、

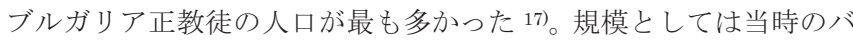
ルカン半島における中程度の都市であったといえよう。

\section{4-1．交易路とタルノヴオ}

19 世紀中葉におけるタルノヴオの交易上の位置を確認しておき たい。1869 年作成のオスマン帝国ドナウ州の地図では、ソフィアと 黒海の港湾都市ヴァルナを結ぶ街道、スタラ山脈とドナウ川の商港 都市ルセを結ぶ街道がタルノヴォで交差しており、内陸の中継点で あったことが理解できる（図 1)。ルセから南下してスタラ山脈を越 える街道は、帝国の首都イスタンブルへとつながる街道であり、ミ ンチョオル\&セルヴェリ商会の文書からはタルノヴオ一ルセ間が陸 運 18)で最短 2 日間 19)、タルノヴオーイスタンブル間が水運もしくは 陸運で 8 日間 20)であったことが判明する。

19 世紀中葉のバルカン半島における交易を考えるうえで最も重 要なのは、1830 年代から開始されたドナウ川の蒸気船定期運航であ る 21)。中欧経済圈とオスマン帝国経済圈を結ぶ交易路のなかでドナ ウ川の重要性が増大寸るのに伴い、従来の主要交易路であった複数 の陸路が衰退した。例えば、中欧およびダルマチア 22 ) とイスタンブ ルを結ぶ街道上に位置していたソフィアは主要流通網からはずれ、 物流量が減少し、19 世紀には衰退の一途を辿っている。一方、ドナ ウ川沿いの複数の商港都市は物流量の増加とともに発展している。 しかし、蒸気船運航の不安定さ、ならびにドナウ川が河口に近づく につれて北上する一イスタンブルから遠のく一という地理的条件か ら、ルセ一イスタンブル間を陸路とする、あるいはルセ一ヴァルナ 間を陸路とし、ヴァルナ一イスタンブル間で再び汽船を用いるとい ラルートは主要な選択肢となっていた。タルノヴォはルセ一イスタ ンブル間の街道上に位置しており、19 世紀中葉においても内陸中継 点としての需要があったと考えられる。

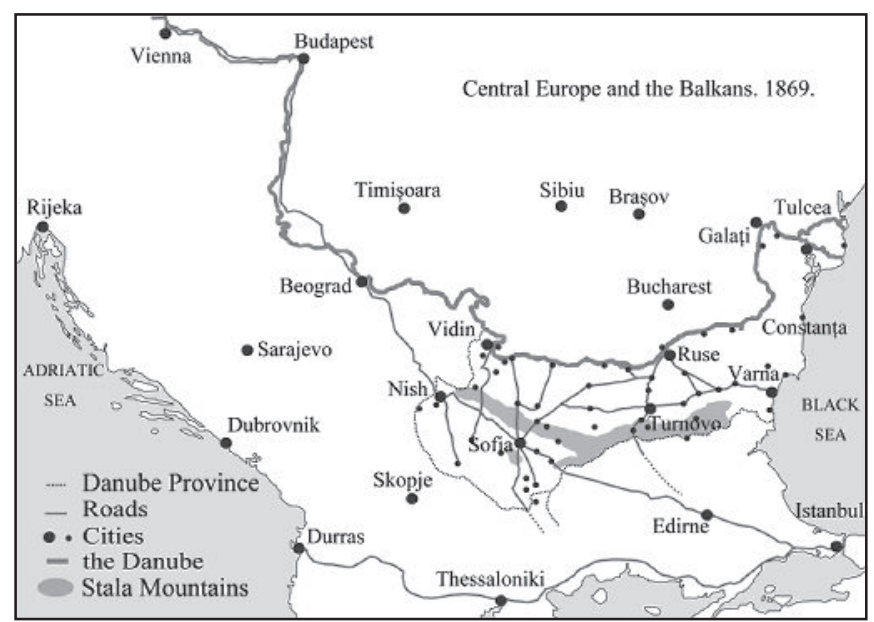

図1 19 世紀後半ブルガリア北部主要都市および街道 （1869 年のオスマン帝国ドナウ州図をもとに筆者作成） 


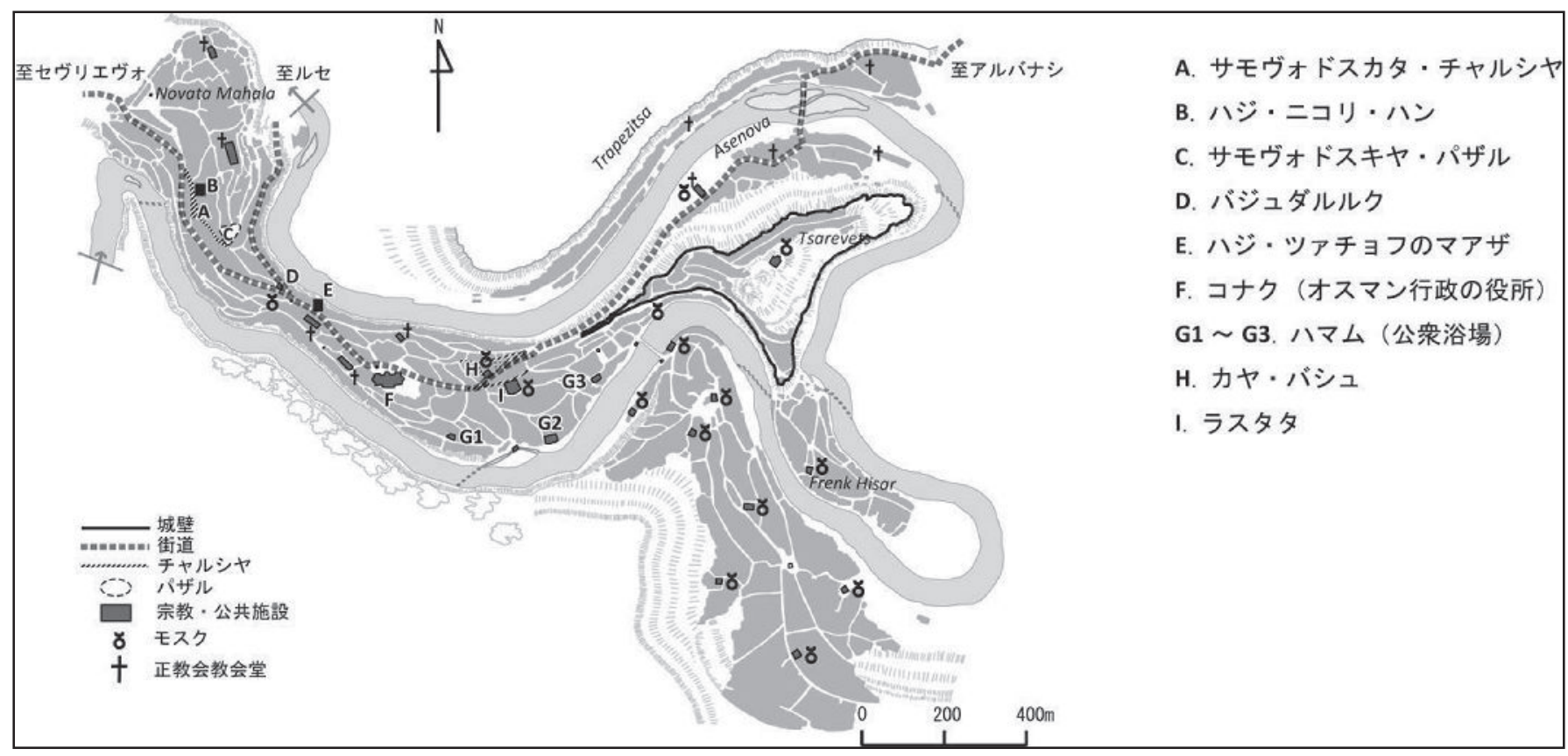

図 219 世紀後半タルノヴォ都市図（1876 年スホムリノフの地図をもとに筆者作成）

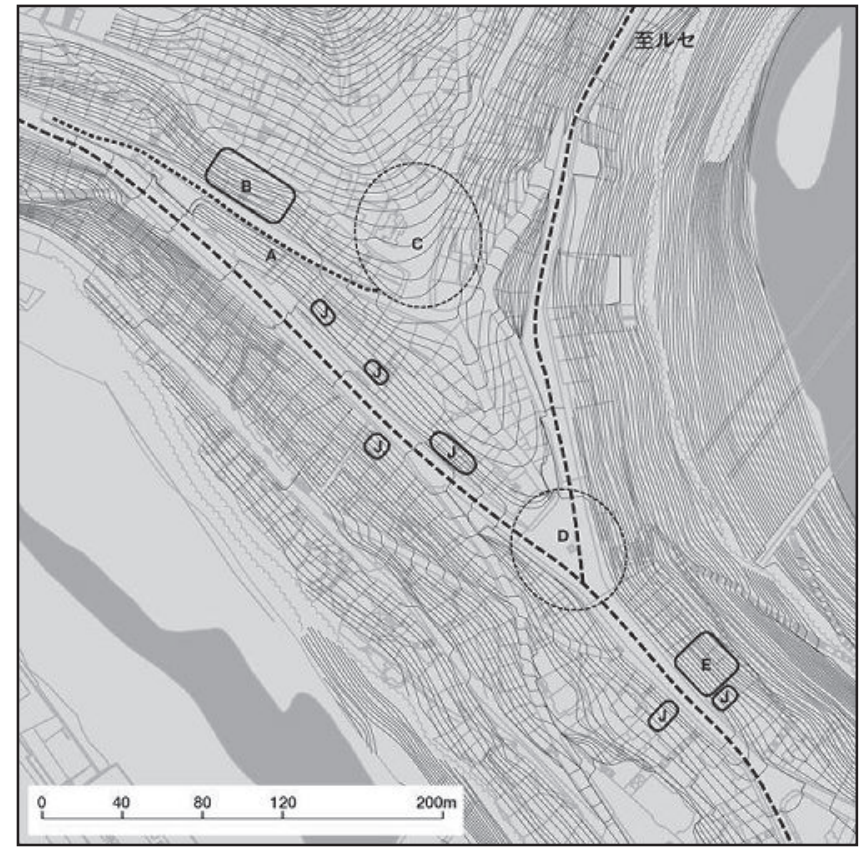

図 3 バジュダルルク、サモヴォドスカタ・チャルシヤ周辺図
A. サモヴォドスカタ・チャルシャ B. ハジ・ニコリ・ハン
C. サモヴォドスキャ・パザルＤ．バジュダルルク
E. ハジ ・ ツァチョフのマアザ J. 現存するマアザ建築

(等高線入り地籍図および 2003 年地籍図をもとに筆者作成)

\section{4-2．タルノヴォにおけるニつの商業地区}

図 2 は 1876 年ロシア軍将校スホムリノフ作成の地図を下敷きに 作成した 19 世紀後半のタルノヴォ市街地図である。地形、街区、 城壁、宗教・公共施設は元の地図をトレースしており、街道、商業 地区、ミンチョオル\&セルヴェリ商会所有のハンとマアザの位置は 筆者が書き込んでいる。スホムリノフの地図、古写真、既往研究 23) を照合すると、19 世紀のタルノヴオに二つの商業中心が存在したこ
とが明らかになる。

一つは「カヤ・バシュ」(Кая баш、図 2-H) と「ラスタタ」(Растата、 図 2-I）一帯の商業地区であり 24$)$ 、中世の城砦地区の西側に隣接し ている。もう一つは、「バジュダルルク」(Баждарлък、図 2-D） 25) から「サモヴォドスカタ・チャルシヤ」(Самоводската чаршия、 図 2-A） 26)にかけての一帯であり、市街地の中でも西側に位置して いる。これら二つの中心商業地区はいずれも市街地の東西を貫く街 道に隣接している。

成立年代は、「カヤ・バシュ」と「ラスタタ」がより古く、「バジ ユダルルク」と「サモヴオドスカタ・チャルシヤ」がより新しいと 考えられる。オスマン帝国時代の市街地形成が東から西へ向かって 展開したことを鑑みると、西側が新しいのが自然である。サモヴオ ドスカタ・チャルシヤが立地する地区は「ノヴァタ・マハラ」(Новата махала、新しいマ八ラ）という名称を持ち、これを裏付ける 27)。

宗教施設の分布からも一つの特性を述べることができる。モスク はバジュダルルク以東にのみ立地し、正教会の教会堂はバジュダル ルク周辺から西にかけて立地する ${ }^{28)}$ 。マハラが宗教施設を核とした 複数街区で形成されることを考えると、宗教施設の分布をマ八ラの 分布に置き換えることで、ムスリムと正教徒のマ八ラ分布の概略を 把握することができる。このことから、カヤ・バシュとラスタタが ムスリムのマハラに立地し、サモヴォドスカタ・チャルシヤが正教 徒のマハラに立地していることが推察される。サモヴオドスカタ・ チャルシヤは唯一モスクのない商業地区であり、正教徒のマハラに 立地している。バジュダルルクにはモスクが隣接しているが、周囲 を正教徒の教会堂に囲まれているため、直ちにムスリムのマハラと 明言することはできない。

\section{4-3. ミンチョオル\&セルヴェリ商会所有の商業施設の立地}

ミンチョオル\&セルヴェリ商会所有のハンはサモヴオドスカタ・ チャルシヤの中ほど、通りの北側に位置し (図 3-B)、マアザはバジ ユダルルクの東約 $100 \mathrm{~m}$ 地点（図 3-E）に位置する。前述のように いずれも相対的に新しい商業地区である。 
バジュダルルクはドナウ川の商港都市ルセからの街道がタルノヴ オを東西に貫く街道と交わる地点である。19世紀中葉におけるドナ ウ交易の増大を考慮すると、ルセ一タルノヴォの発着点という意味 で、バジュダルルクの重要性は大きい。商会所有の二つの商業施設 はバジュダルルクを挟んだ東西に立地している。商会の中心事業は ドナウ川を介した中欧一オスマン帝国間における輸出入と卸売であ り、バジュダルルクはカヤ・バシュやラスタタよりも利便性におい て勝っていたと考えられる。

\section{5. ハジ・ニコリ・ハンに関する分析}

ミンチョオル\&セルヴェリ商会所有のハンは、商会の代表者八 ジ・ニコラ・ハジ・ディモフ・ミンチョオルの名を冠し、「ハジ・ニ コリ・ハン」（Хаджи Николи Хан、1855 年-1858 年建設）という 名を持つ。同商会では 1855 年に創業者の一人であるハジ・ミンチ ヨ・ハジ・ツァチョフが死去し、同年、ミンチョオルによって事業 が引き継がれている。同時に商会は事業の大幅な拡大を行い、タル ノヴォにおいてはハジ・ニコリ・ハンの建設に着手する。

タルノヴオに建設されたハンの中では最大規模であるが、オスマ ン帝国下のバルカン半島南部に建設されたハンとしては決して大き くない。2005 年に筆者が行った実測調查から作成した図面（図 4〜 図 7）に基づいて、ハンの建築的特徴を分析し、機能・利用面につ いても検討したい。

\section{5-1. 構造および形式}

石・煉瓦の組積造で、三階建てである。中庭を中心としたコの字 型プランを持ち、二、三階は中庭に面して柱廊を持つ。屋根は瓦莫 であり、敷地面積は $729 \mathrm{~m}^{2}$ あるる。中庭型複数階のハンはオスマン 帝国時代には一般的かつ典型的であり、バルカン半島南部諸都市の 大型のハンはみなこの形式をとっている 29)。

ハジ・ニコリ・ハンは南側のデュキャン（Дюкян、店舗・工房） 部分 ${ }^{30)}$ と北側・東側のハン部分から構成されている 31$)$ 。サモヴォド スカタ・チャルシヤに南面する正面ファサードは、十軒のデュキャ ンが一列に並ぶ形である。デュキャン群の中央に鉄製の門が設けら れ、トンネルヴオールトの架かった通路で中庭へ引き込む。中庭は チャルシヤの街路と同様、「カルドウルム」（Калдърьм） 32) と呼ば れる石畳の舗装である。八ン部分は L 字型平面である。中庭に面し た一層目外壁は出目地で、二、三層目の外壁は白色の漆喰で仕上げ られている。内壁はすべての部屋で白色の漆喰仕上げである。いず れもバルカン半島南部でよくみられる手法である。ハン部分から実 測図に則って詳細をみていきたい。

\section{5-2. ハン北棟詳細}

ハンの北棟は三層であり、各層とも中庭に面して正方形に近い平 面の房室が並ぶ 33)。一層目中央の階段横には、中庭に面して泉が設 けられている。房室は階段をはさんで西側に三室、東側に二室並び、 各室には中庭から直接アプローチできる。各室の入口部分は中庭の 地盤面から一、二段上がっている。房室はいずれも $20 \sim 22 \mathrm{~m}^{2}$ 程度 の広さで、天井にはドーム状ヴォールトが架けられており、床は敷 石である。誤差はあるものの、間口、奥行、ヴオールト頂上高さは いずれも約 $4.5 \mathrm{~m}$ ですべての房室はほぼ同規模である。中庭側壁面 には上部がアーチ状になった扉が一つ、空が二つ設けられている。 すべての開口部に鉄製の戸が備え付けられており、空の内側にも鉄

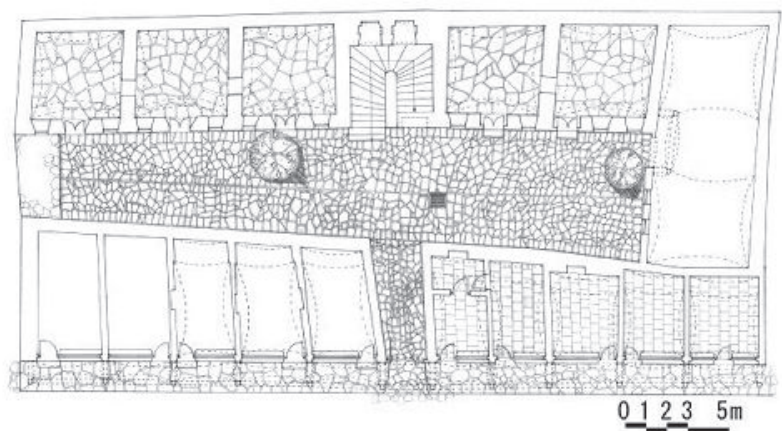

図 4 ハジ・ニコリ・ハンー層目平面図

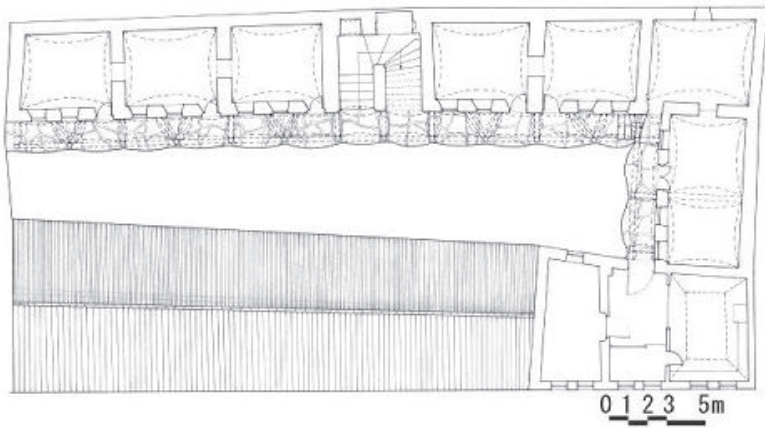

図 5 同二層目平面図

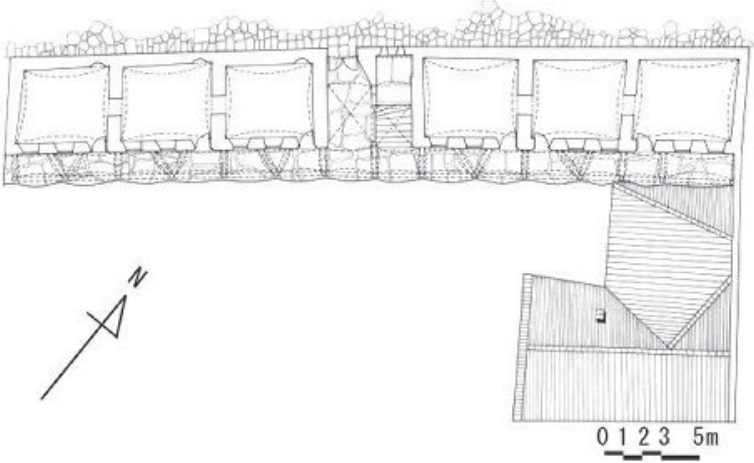

図 6 同三層目平面図

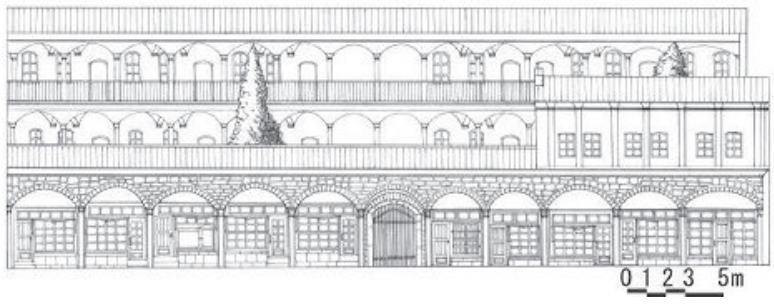

図 7 同南側ファサード立面図

（図 4〜7 は 2005 年の実測結果に基づき筆者作成）

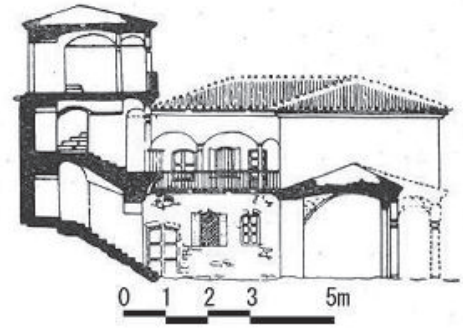

図 8 ハジ・ニコリ・ハン断面図 (Тонев, Л., Кратка История на Българската Архитектура, София, 1965. стр. 368.) 


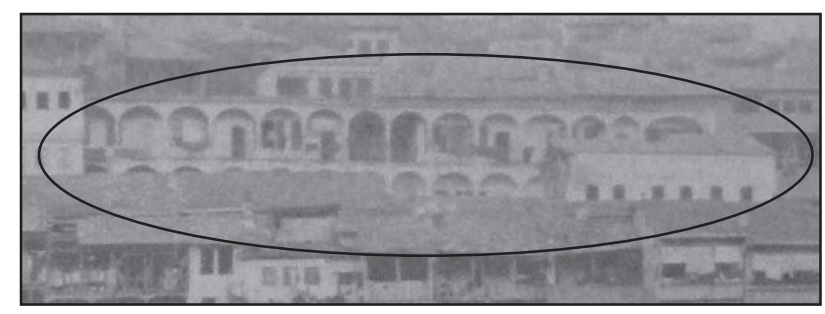

図 91877 年の写真に写るハジ・ニコリ・ハン

(ヴェリコ・タルノヴォ歴史博物館所蔵)

格子が嵌められている。

二層目と三層目は中央の階段を挟んで各三室あり、中庭に面した 柱廊から各房室へアプローチ寸る。柱廊の床面は一階の外壁から迫 り出しており、縁が波形である。柱廊の支柱間にはアーチが架かり、 天井には小さなヴォールトが架かっている。各房室には一層目と同 様に扉が一つ、空が二つ設けられ、天井はドーム状ヴォールトであ る。房室のサイズは一層目に倣っているが、敷地に合わせてやや変 形させてある。ヴォールト頂上高さは二層目で $3.3 \mathrm{~m}$ 程度、三層目 で $3.5 \mathrm{~m}$ 程度である。

\section{5 -3. ハン東棟詳細}

東棟は二層である。実測時点では、一層目は一空間となっており、 地盤面との段差がないことから廐舎・納屋であった可能性が指摘で きる。二層目は北棟から続く柱廊に面して長方形平面の部屋が一つ ある。柱廊の北東角には階段五段分の段差があり、東棟にかけて下 る。これは東棟一層目が地盤面から底上げされていないために階高 が低いことと関係しているのだろう。東棟の柱廊突き当りは南側の デュキャン上にある部屋の出入口である。この部分は他の房室と性 質が違い、一つの空間を三つに仕切り、平天井を架けている。後世 の増築という印象を受けるが、1877 年の写真（図 9）でも存在が確 認できることから建設当初から存在した、もしくは 1877 年までに は建設されていたことがわかる。

\section{5-4．デュキャン部分詳細}

デュキャン部分はサモヴオドスカタ・チャルシヤの街路に南面し、 敷地の端から端までデュキャンを並べる。ハンの両隣の建物と壁面 を共有し、連続的にチャルシヤの一部を構成する。一層の石造で、 中央の門をはさんで両側に五軒ずつ並ぶ。各デュキャンの床面積は 少しずつ異なり、西側ほど大きく、東側ほど小さい。間口はほぼ揃 えられているため、西側のデュキャンは間口に対して奥行が大きい。 前面の歩道は石造の柱廊になっており、各デュキャンの間口に合わ せて支柱が建ち、半円アーチが架かる。柱廊部分はチャルシヤの連 続した歩道の一部である。デュキャンの天井はドーム状ヴォールト (手前) とトンネルヴォールト (奥) の組合せである ${ }^{34)}$

各デュキャンのファサードは実測時点までに改修されている可能 性が大きいが、切石の外壁に木製扉と木枠の大きな嵌め殺し空とい う基本形態はブルガリアのデュキャン一般に共通する要素であるた め、改修があったとしても、当初の形は守られていると考えられる。 商品陳列のためガラス面が大きく、「ケペンク」（Кепенк）と呼ば れる板戸が付属する。ケペンクにはいくつかのタイプがあるが、こ のデュキャン群のケペンクは上には水上げて開口寸る蔀戸と似た仕 組みの板戸で、閉店時には下ろして鉄製の横棒で固定して施錠する。 すべてのデュキャンにおいて中庭側壁面にも高さ $1 \mathrm{~m}$ 程度の半円ア
一チの開口部が設けられているが、現在は壁面に埋め込まれて痕跡 のみが存在する。

\section{$5-5$. 斜面地への対応}

先述したようにタルノヴォは丘陵都市であるため、建物は基本的 に斜面地に建設される。ハンは南北が接道し、東西が隣の建造物と 接する形で建っている。敷地は奥行が約 $18.7 \mathrm{~m}$ であり、等高線入り 地籍図からはその間に 9〜10m の高低差があることが読み取れる。 南のチャルシヤ側地盤面を基準として北側街路地盤面はプラス $9 \mathrm{~m}$ となる（図 8)。ハンは三層目床面がチャルシヤの街路からプラス $9 \mathrm{~m}$ となるように設計されており、三層目は北側の街路にも出入口 を持つ。このことから、ハンの一、二層目北側壁面が崖地の擁壁の 役割を果たしていることがわかる。北街路側のファサードは出入口 の他に開口部がなく、階高一階分の石壁に切妻屋根が架かるだけで ある。八ンの北側が居住地区であり、この街路が商用ではないため であろう。

地籍図に記載された等高線と違い、実際の中庭の地盤がほぼ平ら になっているのは、切土を行い、敷地を造成したためであると推測 できる。これらの工夫は中庭型のハンを崖地に収めるために行われ たと考えられ、中庭型が当地において固定化された商業建築の様式 であったことをうかがわせる。

\section{6. ハンの利用と機能}

ブルガリアにおける 19 世紀のハンの利用については、当地の研 究においても商人と職人による利用という説明がなされるのみで、 詳細な分析は行われていない。ここでは、ハジ・ニコリ・ハンに関 する二枚の文書から当時の利用状況について検討を試みる。

一枚は、「ハジ・ニコリ・ミンチョオルの財務関係文書」としてま とめられた 58 枚の文書のうちの一枚で、このハンのものと推定さ

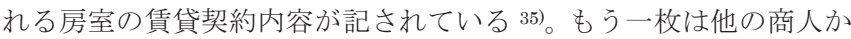

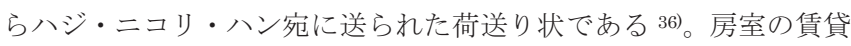
から検討する。

\section{6-1. 房室の貨貸}

文書は 1858 年 4 月 23 日付で、「ハンの中の房室」と明記された 下に 15 房室の賃借人名と賃料が並んでいる。賃貸期間は明記され ていない。200クルシュが六室、250クルシュが五室、他に 400、 350、150、100 クルシュが一室ずつある。賃料、房室数、房室の規 模を照合していくと、200クルシュは三層目の六房室に相当し、250 クルシュは二層目北側の五房室に相当するという推測が成り立つ 37)。貨料の異なる一室ずつは、二層目東側の房室に相当し、広さに より賃料が異なるものと推測する ${ }^{38)}$

このように実際のハンの二、三層目の房室数と文書記載の房室数 が一致していることから、二、三層目の房室はすべて賃貸に出され ていた可能性が高い。一名一室であり、賃借人の名前はほとんどが 非ムスリムである ${ }^{39)}$ 。時計職人が一名含まれており、職人による賃 借があったことが明らかになる。他の賃借人については職業が明記 されていない。ハジ・ニコリ・ハンは 1858 年頃に使用が開始され たと考えられており、ここに記載された人タが初期の房室賃借人で あったと考えられる。

ハン北棟一層目の五つの房室は二、三層目の房室よりも約 $1 \mathrm{~m}$ 天 井が高く、空の格子もより細かく頑丈である。この点は後述するマ 
アザ建築と類似しており、倉庫の性格を持つ空間であるといえる。 上記の文書には「マザ」(Маза、倉庫）40)の賃貸についても記載が あり、三名の正教徒が一つずつ借りている。このマザは一層目の房 室のことを指しており、この時点で三室に借り手がついていたこと を示しているのではないだろうか。このように考えると、ハン部分 はほとんどが貨貸に出されていたことが明らかになる。

\section{6-2．デュキャンと商品売買}

1859 年 12 月 21 日付の荷に同梱されていた送り状からデュキャ ン部分の利用について検討してみたい。送り状は「ミンチョフの八 ン」宛になっている 41)。ハンはこの前年に完成しているため、「ミ ンチョフのハン」はハジ・ニコリ・ハンであると解釈して間違いな いだろう。送り状には、セヴリエヴォのサビ・ストヤンチョフ・カ ラコノオルなる人物がこのハン宛にシュケンベを42)、運送業者を利 用して二つ、自分の車を使用して一つ送ったことと、自分は降誕祭 の後で行くので、もし先に客がいそうなら売ってほしい旨が記され ている。

記載内容からは、ハジ・ニコリ・ハンは荷が運ばれてくる場所で あり、商品売買が行われ、売買の代行も可能であったことが判明す る。カラコノオルのシュケンベは保管され、一部は販売されたとい う状況が想定できる。別の文書からはこのハンに管理人がいたこと も判明しており 43 、管理人のもとに荷を別いた可能性もある。

房室が賃貸に出されていたとすれば、ハンに到着する商品の売買 に使用されたのはチャルシヤに面するデュキャン群であると考えら れる。デュキャンに関しては文書史料による裏付けは得られないが、 賃貸に出されていた記録はない。カラコノオルのケースからは、デ ユキャンでは使用する人物や売買される商品が常に変わり続け、不 特定多数の人と物が出入りしていたことが推察される。到着した荷 は中庭で降ろされ、中庭側にある各デュキャンの小開口部から搬入 が行われ、デュキャンで売買された商品は前面の柱廊部分で荷積み され、また外一出て行くという動線が想定できるのである。

\section{6-3. サモヴォドスカタ・チャルシヤとの関係性}

ハジ・ニコリ・ハンはサモヴォドスカタ・チャルシヤに立地し、 チャルシヤの空間の一部を構成している。チャルシヤにハンが立地 する例は、オスマン帝国下ブルガリアの都市部では一般的であった とみてよい。19 世紀ソフィアの中心商業地区における二つのチャル シヤにも大規模な中庭型のハンが立地していたことが絵図史料から 明らかになっている ${ }^{44)}$ 。ソフィアの場合もチャルシヤに面したハン 部分には複数のデュキャンが組み込まれている。八ジ・ニコリ・八 ンの正面に並ぶデュキャンが、サモヴォドスカタ・チャルシヤのデ ユキャンの一部となることを想定して建設されたのは間違いない。 奥に位置するハン部分は、職人の工房兼店舗や商人の事務所、倉 庫であり、常設市場というチャルシヤの機能に沿っている。デュキ ヤン部分はカラコノオルのようなタルノヴオの外から来る商人にと っても開かれた常設市の店舗である。

ハンとチャルシヤという組み合わせはオスマン帝国下ブルガリア の普遍的な商業空間構成であり、ハジ・ニコリ・ハンとサモヴォド スカタ・チャルシヤはこの形を踏襲していると捉えられる。

\section{7. ハジ・ッァチョフのマアザに関する分析}

ミンチョオル\&セルヴェリ商会ではハンに次ぐ規模の商業施設と してマアザを所有していた。マアザとは、ブルガリアの都市部にみ られた商業施設の一形態であり、一般的に商人の事務所兼倉庫を指 す。マアザ建築は 19 世紀中葉に商人個人により建設されたものが 多いことがわかっている ${ }^{45)}$

ここでは、マアザ建築の一般的特徽について述べた後に、「ハジ・ ツァチョフのマアザ」と呼ばれた同商会所有のマアザに関して、構 造、形式、機能、利用の側面から分析を行う。

\section{7-1. 一般的なマアザの建築的特徵}

図面、写真史料および現存する複数のマアザの観察から、マアザ 建築の一般的な特徵を抽出すると以下のようになる。

石造もしくは煉瓦造の耐火建築で、空間構成には基本となるユニ ットがある。一つのユニットは通常二階建てで、一階は平天井、二 階は円筒ヴォールトが架けられる。フロアに間仕切りはなく、隅部 分に階段が設けられる。妻入りで、三角または弓状のファサードが 接道する。ファサードはシンメトリー構成を基本とし、扉と空は妻 の頂点を基準線として左右対象に配置される。間口は $5 \sim 6 \mathrm{~m}$ 、高さ は $6 \mathrm{~m}$ 程度が一般的である。一ユニットのこともあれば、二、三ユ ニットを並べて一軒のマアザとすることもある。

その他の特徴として、内壁の白い漆喰仕上げ、開口部における鉄 製の格子や雨戸が挙げられる。開口部の仕様に関しては八ン建築と 共通性があり、扉や空上に半円アーチの意匠が見られる。水回りが 備えられておらず、階段が隅部に寄せられていること、二階が屋根 いっぱいまでヴオールト天井になっていることから、商品の保管を 第一義に、できるだけ容量の大きな空間を作り出すことに専念した ことがうかがえる。単純で合理的な空間構成である。

\section{7ー2. ハジ・ツァチョフのマアザの構造および形式}

前節を参考に、ミンチョオル\&セルヴェリ商会所有のマアザに関 して構造および形式を検討する。空間分析には三枚の写真史料を用 いる。(1)「ハジ・ッァチョフのマアザ」と題がついた推定 20 世紀 初頭の正面ファサード(2)1913 年の地震時に崩れたファサード(3) 1900 年頃の北側背面の写真である。

商会創業者ハジ・ミンチョ・ハジ・ツァチョフ（? - 1855 年）の 名が冠されていることから、彼の没年である 1855 年以前に建設さ れた可能性が高い。バジュダルルクの東約 $100 \mathrm{~m}$ の場所に位置し、 市街地を東西に貫く街道に接道していた。

図 3-J はタルノヴオに現存する他の複数のマアザであり、ハジ・ ツアチョフのマアザが他のマアザよりも大型であることがわかる。

写真史料からは、側壁に野石、一階ファサードに切石、二階ファ サードに煉瓦が用いられていることが確認できる。前節で述べたユ ニットを四つ組み合わせて一軒とする構成であるが、建物としては 三ユニットと一ユニットに大別される。左端の一ユニットのみ階高 が異なり、屋根も別に架けられ、ファサードの意匠も異なる。この ことから、元々の建設時期や所有者が異なり、同商会の所有になっ た時点で軒蛇腹を繋げ、ファサードのみを一体化させた可能性が指 摘できる。

間口は三ユニット側が約 $23 \mathrm{~m}$ 、一ユニット側が約 $5.3 \mathrm{~m}$ である。 奥行は建物部分が約 $12 \mathrm{~m}$ 、裏庭部分も約 $12 \mathrm{~m}$ ある。地震時の写真 から二階部分に円筒ヴォールトが架かっていることがわかる。三ユ 


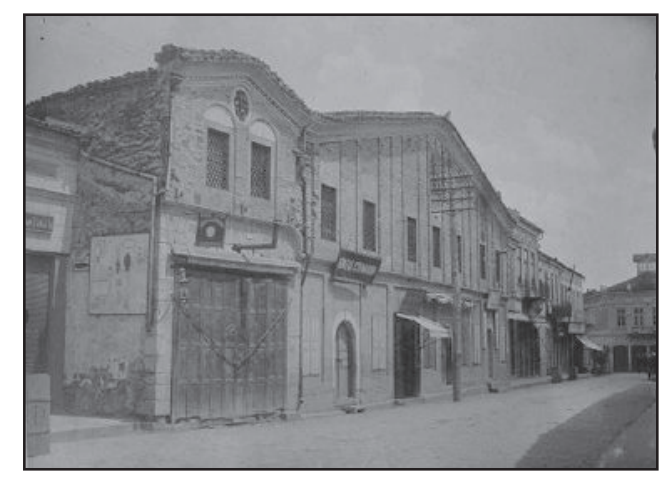

図 10 ハジ・ッァチョフのマアザ正面ファサード (20 世紀初頭)

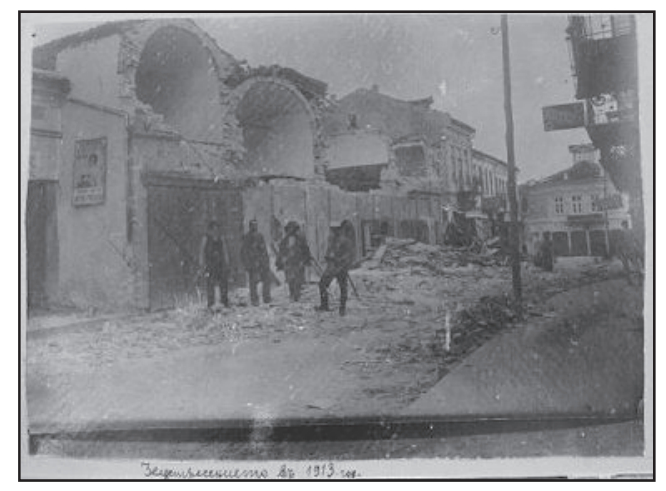

図 111913 年の地震で倒壊したファサード

（図 10、11 ともにヴェリコ・タルノヴォ歴史博物館所蔵）

ニット側は中央が間口も広く二階部分の階高も高い。ファサード全 体がシンメトリー構成になっている他、個々のユニットも開口部が シンメトリーに構成されていることがわかる。開口部の仕様はいず れも前述の一般的なマアザ建築と同様である。

\section{$7-3$. 斜面地への対応}

ハジ・ニコリ・ハンと同様、このマアザにおいても斜面地に建設 するための工夫が施されている。ハジ・ニコリ・ハンが切土で敷地 を造成したのに対し、マアザでは崖地に盛土をして敷地を造成して いる。マアザのファサードが南面する街道は尾根道であり、マアザ が立地する北側に向かって急な崖になっている。等高線からは、建 物の奥行 $12 \mathrm{~m}$ の間に $6 \mathrm{~m}$ の高低差があり、裏庭を含めると奥行 $24 \mathrm{~m}$ の間に $13 \mathrm{~m}$ の高低差が読み取れる。この傾斜地に建物を建てるため、 基礎となる石造の地階を作っており、地階の南側壁面は崖地の擁壁 を兼称ている。北側は石造の擁壁と盛土で造成した裏庭である。等 高線入り地籍図には北側の擁壁が太線で描き込まれており、1900 年の写真でも裏庭を囲むアーチ構造の擁壁が確認できる。同じ写真 には、マアザと並んで、石造の地階を基䃈とした複数階の建造物や 木造の懸造の上に平屋をのせた建物が写っており、いずれも斜面地 における建造スペース確保への工夫が見受けられる。

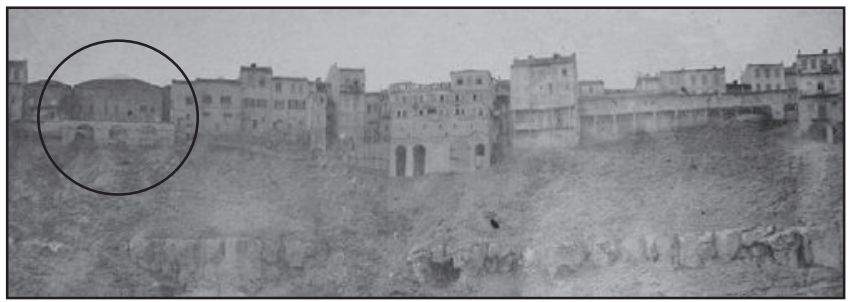

図 12 マアザ北側、1900 年頃 (ヴェリコ・タルノヴオ歴史博物館所蔵)

\section{7-4. マアアザの機能}

一階ファサードはハジ・ニコリ・ハンのデュキャンとは違い、商 品陳列面を持たない。よって小売店のような店舗機能を持つとは考 えにくく、商品の保管機能が最優先で考えられた建物であるといえ る。空間構成からみて二階は倉庫、一階は倉庫兼事務所、地階も倉 庫として使用されたと考えられる。地階の空間構成については史料 がなく、各ユニットから降りられたのかどうか不明だが、後年の等 高線入り地籍図では裏庭は三分割されている。20 世紀初頭の写真で は、各入口に別の看板が掲げられ、それぞれが独立したデュキャン または事務所として使用されていることがわかる。この時点では寸 でに商会は存在しておらず、マアザの所有者は不明である。

\section{7ー5．マアザの利用}

商会の文書に「マアザ」という単語はあまり出てこない。代わり に頻出するのが「マザ」という単語である。「マザ」はアラビア語由 来でトルコ語を経由して流入したブルガリア語であり、倉庫、貯蔵 庫を意味する。民家の地階あるいは一階に設けられた倉庫部分もマ ザと呼ばれる。また、6-1 ではハジ・ニコリ・ハンの一層目房室が マザと呼ばれていた可能性も指摘した。対して、「マアザ」は商人の 事務所・店舗を兼祆た商業倉庫単体に用いられる。しかし、当時の 人々のあいだにおいてもその呼び方の区別は曖昧であり、混同され ている。この商会の場合も両方の単語が用いられている。「マアザ」 あるいは「マザ」という単語が登場する商会の拠点間往復書簡の例 を二通挙げる。

1849 年 3 月 17 日付の書簡には、「メフメト・アガを見つけるよ うに。彼らがタルノヴオのマザに来たときに手形三つ分の金額を徵 収するように。」とある ${ }^{46)}$ 。また、1861 年 3 月 9 日にタルノヴオで 受領された書簡の宛名は、「タルノヴオ、マアザのセルヴェリのイヴ アンチョ・ラデュヴィチュ氏へ」となっている 47 )。二通の書簡はい ずれもミンチョオル\&セルヴェリ商会で働いていたラデュヴィチュ という人物に宛てられたものである。

前者の書簡は、1849 年時点で商会がマザあるいはマアザをタルノ ヴオの拠点として使用していたことを示している。どの建物を指し ているかははっきりとしない。対して後者の書簡は、1861 年時点で ラデュヴィチュがマアザに常駐していたことを示す。1 855 年に商会 の代表者であるミンチョオルがイスタンブルへ、セルヴェリがウィ ーンへ移住したため、同年からタルノヴォの拠点はラデュヴィチュ という人物に任されており、書簡中のマアザはハジ・ツァチョフの マアザであると考えて差し支えないだろう。

ハジ・ニコリ・ハンの大部分が賃貸に出されていたことから、ミ ンチョオル\&セルヴェリ商会自体は、このマアザを自社の事業に使 用していたと考えられる。タルノヴオにおける商品の保管と卸売の 場として使用され、オスマン帝国内外の各拠点間輸送の起点かつ中 継点として中心的な役割を担っていたのがこのマアザであったと考 えられるのである。

\section{8. 結論}

これまでミンチョオル\&セルヴェリ商会所有のハンとマアザにつ いて検討してきた。これらの商業施設はタルノヴオの中でもドナウ 川との結びつき上、最も重要な商業地区に立地していた。

商会が建設したハンやマアザは、形式、チャルシヤや街道沿いと 
いう立地ともに 19 世紀のブルガリア都市部の商業地区に普遍的に みられた形を踏襲している。しかし、タルノヴオにおいては地形の 制約上、崖地に建設されており、定型化された商業建築と地形との 折衝はタルノヴォ固有のものであるといえる。

マアザは商会のための建築であるが、ハジ・ニコリ・ハンは正教 徒のマハラに建設され、房室の賃貸やデュキャンの市場機能をとお して非ムスリムの人々に商工の場を提供している。このことから、 19 世紀のオスマン帝国において、ブルガリア正教徒による一商会が 非ムスリムを主な対象とした公的な商業・交易空間を構築しており、 それがチャルシヤの重要な部分を構成していたことが明らかになる。 一方で、同様の動きが同時代のブルガリア正教徒商人に共通して いたのかどうか、また、イスラーム圈のハン全般において房室の賃 貸や市場機能などが一般的であったかどうかについては不明であり、 今後他の事例を検討しなければならない。

\section{注}

1）アドリア海、エーゲ海、黒海に囲まれた半島部の名称。バルカン諸国とい った場合、現在はアルバニア共和国、ボスニア・ヘルツェゴヴィナ、ブル ガリア共和国、クロアチア共和国、ギリシャ共和国、マケドニア共和国、 モンテネグロ共和国、ルーマニア、セルビア共和国、（コソヴォ共和国、） スロヴェニア共和国のことを指す。バルカン史研究者の柴宣弘は「バルカ ンとは歴史的にビザンツ帝国とオスマン帝国に支配された地域と考える」 とし、「神聖ローマ帝国の支配下に長く置かれたスロヴェニアはこの地域に 含まれない」としている。柴宣弘編著『バルカンを知るための 65 章』明石 書店、2005.4、p.3

2）19 世紀にはまだ国民国家としてのブルガリアは成立していない。1878 年 ベルリン条約でスタラ山脈以北がブルガリア公国として成立、以南が東ル メリア州としてオスマン帝国から自治を獲得。両者の併合は 1885 年、ブ ルガリアの完全独立は 1908 年。オスマン帝国統治下の現在のブルガリア 共和国と重なる領域において、ムスリムと同程度に大きな社会的集団であ ったのはブルガリア語を母語とする正教徒住民であったことから、本稿で は 19 世紀の同地域をブルガリアと呼ぶこととする。

3） 19 世紀のブルガリアでは都市ごとに住民構成が異なっていた。平野部の中 〜大都市では元々ムスリムの入植が進んでいたため、都市によってはムス リム住民のほうが正教徒住民よりも割合が大きいこともあった。小都市で は住民のほとんどが正教徒ということも多かった。

4）ブルガリア正教徒商人とは、オスマン帝国臣民でブルガリア語を母語とす る正教徒であり、特に遠隔地商業に従事した者のことを指す。正教徒商人 については歴史学で研究が進んでいる。Паскалева, В., Средна Европа и Земите по Долния Дунав през XVIII - XIX в., София, 1986. (『18-19 世紀における中欧とドナウ川下流域』）や Papakonstantinou, K., The Pondikas Merchant Family from Thessaloniki, ca. 1750-1800, Merchants in the Ottoman Empire, Paris, 2008, pp. 133-149 など。

5）現、ヴェリコ・タルノヴォ（Велико Търново）。考古学的調査によると、 タルノヴォはビザンツ時代に軍事要塞の一つとして A. D. 5 世紀 6 世紀に 整備されたのが本格的な都市としての出発点であるとされる。Ангелов, Н., Ранновизантийският Град, История на Велико Търново, Том I, София, 1986, стр. 43-57. (「ビザンツ初期の都市」『ヴェリコ・タルノヴォ 市史』第一巻)。

6）ハンは「隊商宿」と訳されることが多いが、すべてのハンが宿泊機能を備 えているわけではないため、ここでは隊商施設という訳語をあてている。 オスマン帝国下のブルガリアで建設されたハンには少なくとも三類型を見 出すことができる。(1)大規模都市型隊商施設(2)小規模都市型隊商施設(3)宿 駅としての隊商施設である。(1) 都市の中心商業地区に立地し、石・煉瓦 造の二、三階建であり、中庭型で複数の房室を持つ。倉庫、商人の事務所 • 店舗、職人の工房 ・ 店舗として使用され、商取引も行われたことから常設 市の機能を持っていたと考えられる。(2)は都市部に立地し、大型家屋の形 態をとる。宿泊と商取引の場であったと考えられる。(3) 都市、村落のい ずれにも立地し、宿泊を主な機能とした隊商施設である。しかし、(1)に宿 泊機能がまったくなかったとはいえない。なお、隊商施設という訳語は、 イスラーム建築研究者である山田幸正がモロッコ・フェズのフンドゥクと
エジプト・カイロのワカーラに、「都市型隊商施設」という訳語を用いたの を参考にしている。山田幸正「モロッコ・フェズにおける都市型隊商施設 (フンドゥク) の建築類型と商業的機能について」『日本建築学会計画系論 文集』第 482 号、1996 年ならびに「エジプト・カイロにおける都市型隊商 施設（ワカーラ）の建築的実態と歴史的変化について」『日本建築学会計画 系論文集』第 489 号、1996 年。

7）マアザは商人の事務所兼倉庫であることから、ここでは商業倉庫という訳 語をあてている。19 世紀中葉にオスマン帝国下ブルガリアの都市部に建設 されたものが多い。商品の保管・商取引の両方の機能を持つ。建築的特徵 に関しては本文 $7-1$ を参照。

8）松井真子による分類。松井真子「オスマン帝国の内国交易政策とムスター ミン商人一ミーリー税を手がかりに一」『日本中東学会年報』第 14 号、 1999 . 3、p. 198 。

ムスターミン商人はキャピチュレーションに基づく恩恵を享受するヨー ロッパ商人のことである。

19 世紀のムスリム商人の活動については史料が不足しており、トルコ史 においても研究が進んでいない。当時のバルカン半島南部におけるムスリ ム商人の実態も不明である。1 8 世紀中葉までは、オスマン帝国の対西欧貿 易におけるムスリム商人勢力は大きかったが、18 世紀を転換点として 19 世紀には非ムスリム商人により独占されていき、ムスリム商人は帝国内の 貿易に従事するようになったといわれている。Quataert, D., The Ottoman Empire 1700-1922, Cambridge, 2000, p. 127 および Faroqhi, S., Introduction, Merchants in the Ottoman Empire, Paris, 2008, p. XVII.

9) ニコラ・ミンチョオル\&エフスタティ・セルヴェリ商会は、1841 年にブ ルガリア正教徒であるハジ・ミンチョ・ハジ・ツアチョフとエフスタティ・ ハジ・ニコロフ・セルヴェリによってタルノヴォを本拠地として設立され た。ドナウ川の汽船による輸送を利用した中欧からの輸入が多く、綿布、 綿プリント、紡績糸、絹、衣類など繊維関係品が大半を占めた。その他に 金属製品、染料、ガラス製品、マッチ、革製品、塩、砂糖、コーヒーなど も輸入している。史料をみる限りでは輸出は品数・量ともに輸入品よりも 少なく、穀物、羊毛、綷、革などである。輸入品はバルカン半島南部の各 大市と商会の各拠点で卸売をしている。顧客は主に正教徒の職人や商人で あり、帳簿に記載された顧客名にムスリムの名が出るのは稀である。1 1855 年に代替わりをし、事業を拡大するが、1865 年に倒産している。ブルガリ ア正教徒の商会としては大きく、タルノヴォでは最大であったと考えられ る。二代目のハジ・ニコラ・ハジ・ディモフ・ミンチョオルはオスマン政 府の徴税請負や各地のブルガリア正教徒とオスマン政府との間の執り成し も行っており、財力・政治力ともに大きかったことがうかがえる。

10) Lowly, H., The Shaping of the Ottoman Balkans 1350-1550, Istanbul, 2008.など、海外ではギリシャ、マケドニアなどバルカン半島南部を扱った ものもみられる。

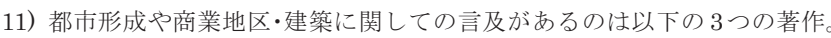
Златев, Т., Битов Пейзаж, Българска Битова Архитектура Книга I, София, 1948, стр. 1-39. (『ブルガリアの建築』) 第一章「ブルガリアの風 景」で都市の景観をメインに、街区構成や隊商施設についても触れている。 Българският Град през Епохата на Възраждането, София, 1955. (『復興期におけるブルガリアの都市』） 19 世紀ブルガリアの都市を公共・ 宗教・商業施設、街路、広場、市場など都市を構成する要素の形態分析を 通して都市全体の構成・形態を明らかにしようとする研究。Българска

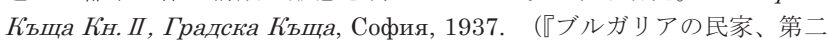
巻、都市の家』)。スタラ山脈麓の小都市カルロヴォを事例にチャルシヤ(常 設市場化した通り。注 26 を参照) の形態に関して述べている。

12) Тодоров, Н., Балканският град XV-XIX век Социално Икономическо и Демогравско Развитие, София, 1972. (『バルカン都市 15 世紀 - 19 世紀 : 社会経済と人口統計学から』)。この研究書の中で、 コライ・トドロフはオスマン語の行政史料を読み解き、18 世紀の不動産所 有状況などについて分析している。

13） 1877 年〜 1878 年の露土戦争準備のために作成されたと考えられる地図。 タルノヴォ全域を含む地図としては最も古い。敷地割が入っていないため 詳細さには欠けるが、当時の市域、街路・街区形態を知ることができ、宗 教施設の位置と名称も記されている。Пътеводителъ на гр. В.-Търново и Околоностъта Му, В.Търново, 1907. (『ヴェリコ・タルノヴォとその周 辺地域に関する案内書』) 巻末付録。

14） 2006 年当時、ヴェリコ・タルノヴオ建築博物館に保存されていた地籍図。 $1 \mathrm{~m}$ ごとに等高線が入っており、 $5 \mathrm{~m}$ ごとに太線で描かれている。

15) 15 世紀からは、ニコポルスキ・サンジャク (Никополски санджак，二 
コポル州。オスマン帝国の行政区分で、現在の北部中央ブルガリア一带） のタルノヴォ・ヴィラエット (Търновски вилает, タルノヴォ県) の中心 都市であった。

16）マハラとは、オスマン帝国下ブルガリアの都市・村落における最小の行 政単位であり、通常、宗教別に形成される。一つのマハラにはモスクや正 教会の教会堂など核となる宗教施設が存在し、隣接する複数街区によって 構成される。18、19 世紀のタルノヴォには正教会聖職者の名を冠したマハ ラが見受けられる。Данова, Н., Към История на Търновската Община през Възраждането, Исторически Преглед, XXXVI, Книга 1, 1980, стр. 106-124. (「民族復興期におけるタルノヴォ自治組織の歴史について」)。 17） 1865 年 12 月 22 日時点でのタルノヴォの人口は 12,874 人である。トル コ人 4,414 人、ブルガリア人 8,241 人と記されており、すでにムスリム、 正教徒という宗教別ではなく民族別に統計をとっているが宗教別と同義だ ろう。Дунав, брой 43. 22 декември 1865 г. (『ドナウ新聞』)。

18）陸運はキラジヤ（Кираджия）と呼ばれる運送業者に委託する。商会お 抱えのキラジャがいたようで、特にタルノヴオールセ間では二つの運送業 者名が頻繁に書簡に登場する。別のルートでは、運送業者をキャラバン (Керван) と表記していることもある。

19）ミンチョオル\&セルヴェリ商会がタルノヴオの拠点からルセの拠点へ送 った書簡から明らかになる。この書簡というのは、主に拠点間で商品や手 形をやり取りするときに同梱されるもので、商取引についての指示などが 記されている。1 1850 年 10 月 19 日にタルノヴオから発送、10月 20 日にル セで受領というのが最短。この場合、移動に丸二日間かかっているものと 考えられる。ДА-В.Търново, Ф82К., Оп.1 а.е. 160 л. 22-23г.

20) イスタンブル 1858 年 2 月 24 日付の書簡が同年 3 月 1 日にタルノヴォで 受領されており、8 日間で物が移動していることになる。イスタンブル— タルノヴォ間は、水運を利用しているとすればイスタンブルから黒海沿岸 の港ヴァルナまでが船で、ヴァルナからタルノヴォは陸路である。ДA-B. Търново, Ф82К., Оп.1, а.е.15, л. 15г.

21） 1829 年にドナウ汽船会社がウィーンで設立され、1833 年にはドナウ河口 まで就航。1 840 年には 17 汽船を持つようになった。

22）現在のクロアチア一帯。

23) Стоянов, И., Обществено-Икономическо и Политичвско Развитие до Войните, История на Велико Търново, Том II, 2000, стр. 361. (「近 代の戦争までの社会・経済・政治的発展」『ヴェリコ・タルノヴオ市史』第 二巻)。

24）「カヤ・バシュ」はトルコ語で「岩の先端」という意味であり、旧城砦 地区の崖の先端にあることからその名がついたと考えられる。一方、「ラス タタ」は、常設市場の一形態であるトルコ語の「アラスタ」に由来すると 考えられる。最初の「ア」が消えた「ラスタ」という単語にブルガリア語 の後置冠詞（英語の the に相当）がついた形で、特定のアラスタを指して いると考えられる。

25）バジュダルルクの語源、由来は不明。1871年にタルノヴォを訪れたユダ ヤ人フェリックス・カニッツの旅行記にも、バジュダルルクの泉に古代ロ 一マの石が使用されていることが印象的であると記されている。Каниц, Ф., Дунавска България и Балканът, София, 1995, стр. 205. (『ドナウ・ ブルガリアとバルカン』)。ミンチョオル＆セルヴェリ商会のデュキャン売 買・賃借記録にもバジュダルルクという地名とモスクの存在が明記されて いる。ДА-В. Търново, Ф82К., Оп.1, а.е. 30, л. 3.

26) チャルシヤは一本の街路とその両側の商業施設（ハン、マアザ、デュキ ヤンなど）から成る常設市場化した通りであり、主体は通りに面したデュ キャンである。同業種ごとに一つのチャルシャを形成する傾向がある。生 産・卸売・小売の寸べてが行われる場である。

「サモヴオドスカタ」は語尾が後続名詞の性により変化しているが、「サモ ヴォデネの」という意味の形容詞で、タルノヴォの北約 $7 \mathrm{~km}$ にあるサモヴ オデネ村に由来すると推測される。サモヴォデネの村人が市に多く来てい たということだろう。

27) Данова, Н., 前注 16 。

28）本稿では、中世の城砦地区北側のアセノヴァ地区は考察の対象としない。 29）ソフィアや南ブルガリアの都市プロヴディフ、マケドニアの首都スコピ エに建設されたオスマン帝国時代の大型のハンもやはり中庭型である。こ れらの都市はタルノヴォよりも規模が大きく、都市一番のハンと目される ものはハジ・ニコリ・ハンの数倍規模である。

30）デュキャンは小売店舗、職人の工房兼店舗、卸売商人の事務所などに使 用される小規模の商業空間であり、通常一部屋である。デュキャンの一般 的な特徴は以下のようになる。(1)一階部分にあり接道する(2)ファサードに
出入口と商品陳列用の大きな開口部を持つ(3)開口部はケペンクと呼ばれる 大きな板戸で開閉される。ハンやマアザ、家屋の一階部分に組み込まれる 場合とデュキャン単体で存在する場合がある。

31）実際には南西を正面として建っているが、本文中では便宜上、南西を南、 南東を東、北東を北、北西を西として記している。

32）ギリシャ語由来のトルコ語に由来する言葉で、中庭、街路、街道の石畳 舗装を意味する。

33）各室の壁が打ち抜かれて行き来できるようになっているのは、後世に博 物館として使用された際の改築と考えられ、ハンとして建設された当時は す心゙て完全な個室であったと考えるのが妥当である。

34）西側二軒のみは平天井だが、これが後世の改築であるか元来のものであ るかは明らかでない。

35) 1858 年 4 月 23 日付でハン房室の賃借人名と貨料が記されている。HБКM БИА, Ф49, а.е. 95 , л. 22 г.

36) ДА-В. Търново, Ф65К., Оп.1, а.е. 45, л.1, 2.

37）二層目のほうが三層目よりも利便性が高く、賃料も高いと考える。

38） 150 クルシュと 100 クルシュの房室はデュキャン上の部屋を二つに分け て貨貸していると推測する。

39）賃借人名のうち、カバクチョオル、ダンカン・チョフェツ（あるいはチ ヨフェジ)、ガウト・マジュドラコオルについては姓名から帰属する宗教を 特定することが難しい。他の賃借人はゲオルギ、ディミタルなど正教系の 名を持っている。

40）詳しくは本文 7-5 索照。

41）「ミンチョオル」という名前表記はトルコ語風であり、「ミンチョフ」は ブルガリア語風である。

42）牛の臟物のこと。当地では一般的な食材。

43) НБКМ, БИА, Ф49, a.e. 33.

44）オーストリア人測量技師兼画家であるヨーゼフ・オーバーバウアーが 19 世紀末のソフィアを描いた水彩画では、タルゴフスカ通りという名のチャ ルシヤと金細工師のチャルシヤにそれぞれ中庭型の大型ハンが建っている のを見ることができる。

45) Тонев, Л. И др., Кратка История на Българската Архитектура, 1965, София, стр. 350-352. (『ブルガリア建築小史』)。

46) ДА-В. Търново, Ф82К., Оп. 1, а.е. 161, л. 4.

47) ДА-В. Търново, Ф82К., Оп. 1, а.е. 122, л. 12.

【技術協力】図 3: 東辻賢治郎。 


\section{THE CONSTRUCTION OF COMMERCIAL BUILDINGS BY BULGARIAN ORTHODOX MERCHANTS AND THEIR SPATIAL CHARACTER}

- The case study of Turnovo in the 19th century -

Yumiko HAYASAKA

JSPS Research Fellow, Faculty of Social Sciences, Hitotsubashi University, Dr. Eng.

This paper will discuss the construction and utilization of commercial buildings in the middle of the nineteenth century in Bulgaria. Very little is known about the real situation of commercial buildings and spaces in Bulgaria at that period, as the few existing studies focus only on either architecture or socio-economic history. This paper addresses these two aspects, while gathering and analyzing data from historical documents regarding Bulgarian orthodox merchants, as well as old pictures, maps, and building plans surveyed and drawn by the author.

In Bulgaria, during the last decades of the Ottoman rule (up to 1878), Bulgarian orthodox merchants increased in number and notoriety. Their trading and commercial activities were developed both inside and outside of the Ottoman Empire. "Nikola Minchoolu \& Evstati Selveli \& Co." (1840s' to 1860s') was one of the biggest companies ever established by Bulgarian orthodox merchants and their head office was located in Turnovo. Turnovo had been an important transit city during the nineteenth century, located in the central northern part of Bulgaria, as two main highways cross here: one marks the route from Sofia to Varna, a port city facing the Black Sea; the other one goes from Ruse, a port city of the Danube, to Istanbul.

Minchoolu \& Selveli \& Co. had its own large commercial building (khan) and storehouse (maaza) in the commercial quarter of Turnovo. The khan, named "Hadzi Nikoli Khan", was constructed in 1858 as a part of Charshija (a permanent market). This building had a courtyard plan, three floors and a stone/brick masonry structure. The ground floor consisted of five rooms (mostly used as storerooms) and ten shops with large display showcases facing the street of Charshija. From this spatial composition, it can be seen that the ground floor functioned as a market, in much the same way as Charshija did. The second floor has eight rooms and the third floor has six. Each room can be accessed from the corridors. A surviving rent contract register book proves that these rooms were rented by merchants and craftsmen to serve as their offices or stu dios.

The storehouse, which is another building owned by them, was probably constructed sometime before 1855 . This type of architecture, called maaza in Bulgarian, contains both a storehouse and an office room. Their maaza is a solid masonry building, with two floors above ground and a basement. It is vertically separated into four units, each of them having one or two entrances. Every ceiling on the first floor is vaulted, in order to maximize space and store as many goods as possible. It is thought that they usually used it for their own goods and business. While the maaza was built for the company's own business, the rooms and shops within Hadzi Nikoli Khan, which was established in the non-Muslim quarter, functioned as a space of trade and craft of non-Muslims.

Regarding these characteristics, it can be said that this private company run by Bulgarian orthodox people provided a certain kind of public space mainly for non-Muslims' commercial and trade activities. It became also evident that these spaces were one of essential components of a permanent market in the nineteenth century Ottoman Empire. 